\title{
Sol-Gel Based Polybenzimidazole Membranes for Hydrogen Pumping Devices DE-FG02-05ER46258
}

\author{
Brian C. Benicewicz ${ }^{\mathrm{a}}$, Glenn A. Eisman ${ }^{\mathrm{b}}$, and S.K. Kumar ${ }^{\mathrm{c}}$, S.G. Greenbaum ${ }^{\mathrm{d}}$ \\ ${ }^{\mathrm{a} D e p a r t m e n t}$ of Chemistry and Chemical Biology, Rensselaer Polytechnic Institute, 110 8th \\ Street, Troy, NY 12180 USA \\ ${ }^{b}$ Department of Materials Science and Engineering, Rensselaer Polytechnic Institute, 110 \\ 8th Street, Troy, NY 12180 USA \\ ${ }^{\mathrm{c}}$ Department of Chemical Engineering, Columbia University, New York, NY USA \\ ${ }^{\mathrm{d}}$ Department of Physics, Hunter College, New York, NY USA
}

\begin{abstract}
Electrochemical hydrogen pumping using a high temperature $\left(>100^{\circ} \mathrm{C}\right) \mathrm{PBI}$ membrane was demonstrated under non-humidified and humidified conditions at ambient pressures. Relatively low voltages were required to operate the pump over a wide range of hydrogen flow rates. The advantages of the high temperature capability were shown by operating the pump on reformate feed gas mixtures containing various amounts of $\mathrm{CO}$ and $\mathrm{CO}_{2}$. Gas purity measurements on the cathode gas product were conducted and significant reductions in gas impurities were detected. The applicability of the PBI membrane for electrochemical hydrogen pumping and its durability under typical operating conditions was established with tests that lasted for nearly 4000 hours.

\section{Introduction}

The development of efficient, cost effective, reliable, and scale-able hydrogen separation, purification, and pumping technologies are key requirements for the advancement of a hydrogen economy. Additionally, hydrogen is a key reactant and/or by-
\end{abstract}


product in numerous existing industrial processes such as ammonia production, oil refining, methanol production, hydrogenation processes, and metallurgical heat treating operations, to name a few. In many processes, separation of hydrogen is desired to enhance the $\mathrm{H}_{2} / \mathrm{CO}$ ratio in synthesis gas produced from the gasification of coal and other carbon-based fuels, including the steam reforming of natural gas. In addition it is also desirable to control the $\mathrm{H}_{2} / \mathrm{N}_{2}$ ratio in purge streams in ammonia production; and to regulate the $\mathrm{H}_{2} /$ hydrocarbon ratio in petrochemical processes. ${ }^{1-3}$ Advancements in hydrogen purification technology will support the use of hydrogen as a heat and energy carrier for portable, in emerging stationary, and transportation applications. Proton exchange membrane fuel cells (PEMFC) systems which generate hydrogen from natural gas or propane in a reformer currently use water gas shift reactors, a preferential oxidation of $\mathrm{CO}$ stage, and methanation to enhance the hydrogen content of the processed hydrocarbon. ${ }^{4}$ As in any device, the desired properties of an appropriate separation technology are durability, mechanical robustness, productivity, separation efficiency, and cost.

Purification of hydrogen contributes significantly to the cost of hydrogen production depending on the desired final gas quality. Hydrogen may be generated from biofuels, coal, petroleum, natural gas, and other hydrocarbon feed sources. In these reformation processes, hydrogen is commonly accompanied by contaminant gases, such as carbon dioxide, carbon monoxide, and nitrogen.

Current purification technologies include pressure swing adsorption (PSA), cryogenic distillation, metal hydride purification, and membrane separation (polymer, ceramic, metallic) separation. Many of these purification methods are energy intensive processes, require significant excess hydrogen venting, or are expensive to operate. PSA, 
cryogenic distillation, and metal hydride technology require multiple vessels and in some instances may require additional wash columns to remove $\mathrm{CO}$ and $\mathrm{CO}_{2} \cdot{ }^{5-7}$ Three types of membrane separators include palladium, microporous silica, and carbon based materials. These separators rely on high pressure feed streams to produce pure hydrogen and commonly experience hydrogen embrittlement. ${ }^{5,6}$ Thus, additional costs related to the generation of high pressure must be considered in the final application.

Electrochemical hydrogen pumping based on low temperature proton exchange membranes was originally developed in the 1960 's. ${ }^{8,9}$ Fundamentally, an electrochemical pump is designed to oxidize and reduce hydrogen at the anode and cathode, respectively in an electrolytic mode. As shown in Figure 1, a hydrogen-containing stream enters the anodic compartment of a cell and molecular hydrogen is oxidized to protons and electrons at the three phase interface of the catalyst, electrolyte, and gas. The protons are then "driven" through the membrane from the applied potential difference between the two electrodes, while the electrons are driven through the electrically conductive elements of the cell to the cathode. The protons and electrons are combined to form molecular hydrogen in the cathodic compartment.

The major difference in this cell as compared to a fuel cell is that the electrochemical hydrogen pump is operated in an electrolytic mode, as opposed to galvanic. Thus, the electrochemical pump requires power to complete the chemical reactions. Since the oxidation and reduction of hydrogen reactions are facile and are nearly Nernstian in their electrochemical behavior, and by definition the exchange reactions occur at zero volts for hydrogen (vs. SHE), minimal power should be required to operate the cell. Additionally, the hydrogen purity produced at the cathode is predicted to be high although 
such purity is dependent on the permeability of the membrane separator with respect to the incoming gas streams, the integrity of the membrane, the water content of the membrane (if Nafion-based). However, the original work based primarily on perfluorosulfonic acid based membranes was constrained by the same gas purity requirements that are imposed on today's PEMFCs that operate at temperatures up to $\sim 80^{\circ} \mathrm{C}$, i.e., the hydrogen stream was not processable if it contained carbon monoxide. Limited work on electrochemical pumping has also been published using phosphoric acid and molten carbonate fuel cell technology. ${ }^{6,10,11}$ Literature on hydrogen pumping using proton-conducting ceramic membranes can be found elsewhere. ${ }^{12,13}$

Low temperature $\left(<100^{\circ} \mathrm{C}\right)$ PEM-based electrochemical hydrogen pumping is capable of separating hydrogen as long as the other gas constituents do not poison the catalyst or diffuse through the membrane. ${ }^{10,14-22}$ When platinum is the catalyst in a low temperature PEMFC, one such undesirable impurity is carbon monoxide $(\mathrm{CO})$ as it adsorbs onto the catalyst surface and inhibits its electrochemical activity. Low temperature PEMFCs can suffer significant performance losses if the CO levels are greater than few ppm and thus impose similar restrictions for low temperature hydrogen pumps. ${ }^{23}$ As a result, little activity or development has focused on the low temperature perfluorosulfonic acid-based pump technology.

The demands of a water based electrolyte led researchers in the early 1990s to investigate phosphoric acid doped membranes that offered increased tolerance to fuel impurities and faster electrode kinetics. ${ }^{24}$ Operation at temperature above $100 \mathrm{C}$ required a thermally and chemically stable membrane. Polybenzimidazole (PBI) doped with phosphoric acid was recognized in the literature since the early 1990s for its great potential 
in fuel cell applications. ${ }^{25-30}$ The conventional method to produce PBI membranes commonly involved placing a preformed membrane in a phosphoric acid bath or casting PBI from a solvent acid mixture. Proton conductivity of a PA doped PBI membrane in literature range from $10^{-15}$ to $0.13 \mathrm{~S} / \mathrm{cm} \geq 160^{\circ} \mathrm{C}$. It was suggested that a proton hopping mechanism occurs in PA doped PBI membranes. This mechanism is supported by experiments that measured negligible electro-osmotic drag coefficient and NMR results that found phosphoric acid to be less mobile in the membrane and than in the solution state. ${ }^{31,32}$

Recently, PBI membranes have been developed by a new sol-gel process which produces phosphoric acid (PA) doped PBI membranes with higher levels of PA and ionic conductivities than previously reported, while maintaining mechanical integrity. ${ }^{33}$ This new synthetic pathway has also allowed for different chemistries of PBI to be investigated for various applications. They have been shown to operate at high temperatures (up to $200^{\circ} \mathrm{C}$ ) for extended periods of time without the need for feed gas humidification and with low degradation rates. It has also been shown that the $\mathrm{CO}$ tolerance of the platinum catalyst at these temperatures is greatly increased. In this paper, we describe electrochemical hydrogen pumping using a high temperature PBI membrane processed via the sol-gel process. Initial tests were performed to investigate the electrical efficiency, power consumption and durability of the MEAs. Two simulated reformate streams with varying concentrations of $\mathrm{H}_{2}$ and $\mathrm{CO}$ were used to establish the increased utility of hydrogen pumping when using a high temperature PBI membrane. The purification of hydrogen that is inherent in an electrochemical pump was demonstrated by measuring the gas purities of the exhaust hydrogen.

\section{Experimental}


Terephthalic acid $\left(99^{+} \%\right.$ pure) from Amoco and 3,3',4,4'-tetraaminobiphenyl (polymer grade) donated by Celanese Ventures, $\mathrm{GmbH}$ were polymerized in polyphosphoric acid (115\%) from Aldrich Chemical Co. or FMC Corporation. The solution was then cast at $220^{\circ} \mathrm{C}$ with a 15 mil Gardner casting blade. The parapolybenzimidazole films were then placed in a 55\% relative humidity chamber for approximately $24 \mathrm{hrs}$, where the polyphosphoric acid hydrolyzed to phosphoric acid initiating a sol to gel transition. Three individual polymerizations were performed. Further synthetic details can be found elsewhere. ${ }^{33}$

Titration of the membranes with a $0.100 \pm 0.001 \mathrm{M} \mathrm{NaOH}$ solution using a Riedelde Haën titrator and drying in a $120^{\circ} \mathrm{C}$ oven permitted calculation of the average acid doping level of the initial films at $37.0 \pm 2.1$ moles of phosphoric acid per polymer repeat unit.

The polymer was crushed and then neutralized with ammonium hydroxide. The polymer was thoroughly washed with distilled water and then vacuum dried at $120^{\circ} \mathrm{C}$ overnight. Solutions of approximately $0.2 \mathrm{~g} / \mathrm{dL}$ in $96 \%$ sulfuric acid were prepared. The inherent viscosities were measured using a Cannon Ubbelohde viscometer at $30.0^{\circ} \mathrm{C}$. The resulting inherent viscosities for the three batches were $2.77,2.98$, and $3.65 \mathrm{dL} / \mathrm{g}$.

Using a four-probe AC impedance method from $1 \mathrm{~Hz}$ to $100 \mathrm{kHz}$ with a Zahner IM6e spectrometer, ionic conductivities were calculated to be approximately $0.28 \mathrm{~S} / \mathrm{cm}$ at $160^{\circ} \mathrm{C}$ after an initial heating to remove the water. Additional details can be found in a previous publication. ${ }^{33}$

The electrochemical pump assembly was similar to that previously published for a fuel cell. ${ }^{33}$ Etek electrodes $\left(1.0 \mathrm{mg} \mathrm{Pt} / \mathrm{cm}^{2}\right)$ with Kapton frames were hot pressed to the 
polybenzimidazole films at $140^{\circ} \mathrm{C}$ for $30 \mathrm{sec}$ with a manual Carver press. The active area was approximately $10 \mathrm{~cm}^{2}$. Stainless steel end plates and graphite flow fields were used to maintain good electrical contact and distribute the fuel. The current and voltage were recorded with an electronic load attached to a PC using LabView Software from National Instruments in Austin, TX. All cells were operated for at least 100 hours at $160^{\circ} \mathrm{C}, 0.2$ $\mathrm{A} / \mathrm{cm}^{2}$ with nonhumidified hydrogen ( $>1$ stoichiometric flows). The conditions of the steady-state current plots were $160^{\circ} \mathrm{C}$ at $0.2 \mathrm{~A} / \mathrm{cm}^{2}$, with varying inlet stoichiometric flows of hydrogen regulated by mass flow controllers or rotometers. The gas streams were supplied directly from commercially available tanks without external humidification, except where humidification is noted. The external humidification was controlled by a water bath held at $60^{\circ} \mathrm{C}$, resulting in approximately $3 \%$ relative humidity at $160^{\circ} \mathrm{C}, 6 \%$ at $140^{\circ} \mathrm{C}$, and $10 \%$ at $120^{\circ} \mathrm{C}$. The pressure was not regulated and open to the atmosphere. All tests were performed at $160^{\circ} \mathrm{C}$, except one set of experiments that investigated the relationship between temperature and performance. The fuels included pure hydrogen, premixed natural gas reformate $\left(35.8 \% \mathrm{H}_{2}, 1906 \mathrm{ppm} \mathrm{CO}, 11.9 \% \mathrm{CO}_{2}\right.$, and $\mathrm{N}_{2}$ balance) and premixed methanol reformate (1.03\% $\mathrm{CO}$ and $29.8 \% \mathrm{CO}_{2}$ with $\mathrm{H}_{2}$ balance). The outlet flow rates were measured by a MKS $200 \mathrm{sccm}$ mass flow meter calibrated for hydrogen. With the assistance of $\mathrm{H}_{2}$ Pump, $\mathrm{LLC}, \mathrm{CO}$ and $\mathrm{CO}_{2}$ concentrations were determined to the ppm level with a HP 5890 Series II gas chromatograph with a 15' X 1/8” Carboxen column and hydrogen carrier gas. The column was connected to a nickel methanizer at $400^{\circ} \mathrm{C}$ and a flame ionization detector.

\section{Results and Discussion}


The basic concept of electrochemical pumping in the presence of a mixed feed stream is shown in Figure 1. Electrochemical cells were operated from 120 to $160^{\circ} \mathrm{C}$ on various fuel streams with and without external humidification, in order to investigate power requirements, electrochemical efficiency, durability, $\mathrm{CO}$ tolerance, and purification efficiency.

The nearly Nernstian behavior of the oxidation and reduction of hydrogen are predicted and therefore the device is expected to require minimal power to drive the electrolysis of hydrogen. An electrochemical pump was operated at $160^{\circ} \mathrm{C}$ on approximately 1.2 times that of the stoichiometric requirements of pure hydrogen without external humidification at the anode for its entire lifetime. Polarization curves of the cell were obtained to investigate its power requirements as shown in Figure 2. The curves are relatively consistent up to $1 \mathrm{~A} / \mathrm{cm}^{\wedge} 2$ and exhibit a relatively linear relationship between voltage and current. At a typical operating current densities of $0.2 \mathrm{~A} / \mathrm{cm}^{2}$, electrochemical pumping of hydrogen required relatively low voltages at $160^{\circ} \mathrm{C}$, i.e., $45 \mathrm{mV}$ for all scans, except the reverse scan of voltage step curve. The $1 \mathrm{hr}$ scan from $0-1 \mathrm{~A} / \mathrm{cm}^{2}$ has excellent reversibility. The electrochemical hydrogen pump was able to achieve the set maximum current density of $2.0 \mathrm{~A} / \mathrm{cm}^{2}$. The low voltages required to operate the hydrogen pump result from facile oxidation and reduction of hydrogen and the low resistances of the MEA and cell hardware components.

In general, the voltage in Figure 2 diverged at high current densities and then converged again at lower potentials. The forward and reverse curves were analyze separately with linear regression, using one or two lines to fit the linear regions between 0 to $1.5 \mathrm{~A} / \mathrm{cm}^{\wedge} 2$. The maximum error of $15 \Omega$ was observed for the manual curves, which is 
potentially a result of variable voltage step sizes. The scanned polarization curves exhibit an error of less than $1 \Omega$. The range of resistance values including the linear regression errors can be reduced into two groups: $209-251 \Omega$ and $384-433 \Omega$. Seventy-five percent of the time, the current density ranges $0-1 \mathrm{~A} / \mathrm{cm}^{2}$ and $1-2 \mathrm{~A} / \mathrm{cm}^{2}$ followed this transition in resistance. These curves indicate that the electrochemical cell undergoes a change from relatively low resistance to high resistance at $1 \mathrm{~A} / \mathrm{cm}^{2}$ with changes in potential. Mass transport losses can also affect the voltage at high current densities.

Unlike conventional purification methods that rely on pressure differentials and thermal cycling, an electrochemical hydrogen pump generates hydrogen at a rate dependent on the applied current. Faraday's law dictates that the flow of hydrogen, $\mathrm{dn} / \mathrm{dt}$, is directly proportional to the current, I,

$$
\mathrm{I}=\mathrm{nF} \mathrm{dn/dt}
$$

where $\mathrm{n}$ is the number of electrons and $\mathrm{F}$ is Faraday's constant. The current efficiency, $\varepsilon_{\text {current }}$, is the ratio between the expected Faradic flow and the measured value.

In order to compare the performance of the high temperature electrochemical pump to previous work, overall efficiency $\left(\varepsilon_{\text {total }}\right)$ is the product of voltage and current efficiencies.

$$
\varepsilon_{\text {total }}=\varepsilon_{\text {current }} * \varepsilon_{\text {volt }}
$$

The definition of voltage efficiency ( $\varepsilon_{\text {voltage }}$ ) defined by Sedlak et al. and Lee et al. will be employed, using the heat of combustion of hydrogen, $1.484 \mathrm{~V} .{ }^{17,22}$

This $\varepsilon_{\text {voltage }}$ excludes losses from entropy and potential differences in the cell. An alternative definition of $\varepsilon_{\text {volt }}$ utilizes the maximum practical theoretical voltage $(0.8 \mathrm{~V})$ of a 
fuel cell. Ibeh et al. defined $\varepsilon_{\mathrm{volt}}$ as the following to include the three types of losses associated with fuel cells: activiation, Ohmic, and mass transport. ${ }^{34}$

$$
\varepsilon_{\mathrm{volt}}=1-(\mathrm{V} / 0.8)
$$

Investigation of the current efficiency of the electrochemical pump was conducted by measuring the cathodic outlet hydrogen flow at varying current densities. As shown in Figure 3, an electrochemical cell operated with approximately 1.2 stoichiometric flows of hydrogen without external humidification produced a cathodic outlet flow that increased linearly with current density. The measured values were nearly identical to theoretical Faradic flows. It was also visually observed and measured that the cathodic outlet stream immediately stopped at $0 \mathrm{~A} / \mathrm{cm}^{2}$, indicating that gas diffusion through the membrane and crossover leaks were minimal. The current efficiencies were calculated to be greater than $83 \%$ from 0 to $2 \mathrm{~A} / \mathrm{cm}^{2}$. More specifically, current efficiencies greater than $90 \%$ were achieved at current densities greater than or equal to $0.4 \mathrm{~A} / \mathrm{cm}^{2}$. The maximum total efficiency, including voltage based on the thermal energy of hydrogen and current efficiencies, was $85 \%$ at $0.4 \mathrm{~A} / \mathrm{cm}^{2}$. (The maximum total efficiency based on theoretical fuel cell operation was found at the same current density and was $81 \%$.) Thus, the electrochemical hydrogen pump using a PBI membrane and operating on non-humidified gases achieved relatively high efficiencies, while generating nearly Faradic flows.

The durability of the electrochemical pump was investigated at a steady current density of $0.2 \mathrm{~A} / \mathrm{cm}^{2}$ at $160^{\circ} \mathrm{C}$, while operating on pure hydrogen without external humidification. The voltage vs. time plot shown in Figure 4 exhibits an initial period with some variability that has been attributed to the evaporation of $\mathrm{H}_{2} \mathrm{O}$ from the membrane and removal of the water from the cell hardware. However, the voltage was found to be 
relatively constant at $22 \mathrm{mV}$ for over $2,000 \mathrm{hrs}$ of operation. This voltage is similar to the values achieved in the reverse scan on the polarization curve shown in Figure 2. It was observed that the cell had an essentially instantaneous response between current and cathodic outlet flow. The voltage spikes and dips were from unintended shutdowns due to building power outages and station events.

The effects of relative humidity $(\mathrm{RH})$ were investigated by cycling the $\mathrm{RH}$ between 0 and $3 \%$ at $160^{\circ} \mathrm{C}$. This experiment was conducted by alternately connecting and disconnecting the pure hydrogen feed stream to a $60^{\circ} \mathrm{C}$ water bath. The cell was held at 0.2 $\mathrm{A} / \mathrm{cm}^{2}$ with $\sim 2$ stoichiometric hydrogen flows for the first 150 hours, and then $\sim 5$ stoichiometric hydrogen flows for the remainder of the test. The voltage response for this cycling test is shown in Figure 5. There were not any significant differences in voltage between the high and low flow operations in this limited test. The average voltage during the non-humidified cycle was approximately $33 \mathrm{mV}$ and decreased to $18 \mathrm{mV}$ under humidified operation. The voltage during the non-humidified cycle was in good agreement with the reverse scan of the voltage step polarization curve of Figure 2. The humidification level was found to directly affect the voltage and improved performance at $3 \%$ relative humidity in a cell operating at $160^{\circ} \mathrm{C}$. It is proposed that the voltage drop is related to a reduction in the electrode resistance. The presence of $\mathrm{H}_{2} \mathrm{O}$ molecules in the electrode layer could increase the area of the three phase interface between catalyst particles, hydrogen gas molecules, and phosphoric acid (and water) electrolyte. Electrochemical impedance spectroscopy is currently being utilized to investigate this voltage drop upon humidification. However, other work in our laboratory suggests that this level of humidity would not be responsible for significant changes in membrane resistance. Even under these 
relatively severe test conditions of gas feed humidification and drying-out, the PA-doped PBI based cell maintained stable voltages during each cycle and a lifetime of 4,000 hrs until an unintended station event. This evidence supports the hypothesis that the PBI membranes are able to retain sufficient phosphoric acid under non-humidified and humidified operation for extended periods of time.

The power requirements of non-humidified and humidified operation were investigated by obtaining polarization curves at $160^{\circ} \mathrm{C}$ during each cycle. The hydrogen inlet feed stream was adjusted to maintain 1.2 stoichiometric flows at each current density for the humidified polarization curve. For the nonhumidifed polarization curve, a constant flow of $\sim 75 \mathrm{~mL} / \mathrm{min}$ of hydrogen was supplied up to a current density of $0.8 \mathrm{~A} / \mathrm{cm}^{2}$ and then the voltage steps were continued at 1.2 stoichiometric flow operation. After the flow and current density were adjusted, the current density was held constant for 3 minutes and then the voltage was recorded. Both polarization curves are shown in Figure 6 and exhibit a relatively linear relationship between voltage and current. The voltages from the polarization curves at $0.2 \mathrm{~A} / \mathrm{cm}^{2}$ were $30 \mathrm{mV}$ during the nonhumidified cycle and $15 \mathrm{mV}$ during the humidified cycle. These voltages are in good agreement with steady state values for this cell under the same conditions, which were 33 and $18 \mathrm{mV}$. Both polarization curves extrapolate to approximately $0 \mathrm{mV}$, which indicates that there was essentially zero $\mathrm{pH}$ difference across the cell. The total resistance $(75 \Omega)$ during the humidified cycle calculated from the slope of the polarization curve is nearly half of the nonhumidified cycle $(159 \Omega)$. In contrast, the electrochemical cell that was feed a constant stream of nonhumidified gas has a resistance that is a nearly third larger than the nonhumidified cycle and then increases to fifty percent higher above $1 \mathrm{~A} / \mathrm{cm}^{2}$. The time length $(150 \mathrm{hrs})$ of the 
nonhumdified cycle is mostly likely not the differentiating factor because the nonhumidified cell in Figure 2 had polarization curves obtained at $\sim 170$ hrs. For comparison, the data from Ströble et al. is shown for a humidified Nafion membrane operating at $70^{\circ} \mathrm{C}{ }^{18}$ Significantly lower voltages were observed for PBI membranes under humidified (3\% RH) conditions. Low levels of humidification reduced the total resistance related to bipolar plates, electrode, and PA-doped PBI membrane. Similarly, equivalent or lower voltages were obtained under non-humidified conditions, which are difficult to achieve with a water electrolyte membrane system.

The current work shows that the high temperature electrochemical hydrogen pump requires low voltages, achieves nearly Faradic flows, and has excellent durability. The main advantage of the high temperature electrochemical pump is its predicted ability to operate in the presence of contaminants. For example, $\mathrm{CO}$ tolerance increases at higher operating temperature because the $\mathrm{CO}$ desorption rate on platinum increases at higher temperatures. In order to test the tolerance of the pump to variations in feed streams, the anodic inlet of a cell was varied between pure hydrogen, a premixed natural gas reformate (35.8\% $\mathrm{H}_{2}, 1906 \mathrm{ppm} \mathrm{CO}$, and $11.9 \% \mathrm{CO}_{2}$ with a $\mathrm{N}_{2}$ balance), and a premixed methanol reformate ( $1.03 \% \mathrm{CO}$ and $29.8 \% \mathrm{CO}_{2}$ with a $\mathrm{H}_{2}$ balance). The cathodic outlet flow was measured at $0,0.2$, and $0.4 \mathrm{~A} / \mathrm{cm}^{2}$, while operating on each feed stream at a constant flow rate as shown in Figure 7. The cathodic outlet flows from different feed streams were essentially identical causing the difference symbols to overlap in the flow rate vs. current density plot. The cathodic outlet flow was relatively independent of the feed stream, which contained diluted hydrogen and high levels of $\mathrm{CO}$ and $\mathrm{CO}_{2}$. The cell also achieved nearly Faradic flows, regardless of inlet composition. 
The effect of $\mathrm{CO}$ desorption rate was further investigated by varying the operating temperature of a high temperature electrochemical pump with an anode feed stream containing 1\% CO (Figure 8). Initially, a cell which had been subjected to a 2100 hour durability test was subsequently operated at $0.2 \mathrm{~A} / \mathrm{cm}^{2}$ on a humidified hydrogen stream (humidifier bottle temperature $60^{\circ} \mathrm{C}$, approx. 3\% RH) for 175 hours (from $2125 \mathrm{hr}$ to 2300 hr) at $160^{\circ} \mathrm{C}$ at a voltage $<25 \mathrm{mV}$. The gas feed was then changed to a premixed synthetic reformate containing 1\% CO (at $2300 \mathrm{hr}$ ). The effect of the CO was observed immediately by the increase in voltage to approximately $38 \mathrm{mV}$. A stepwise reduction in temperature to $140^{\circ} \mathrm{C}$ and $120^{\circ} \mathrm{C}$ caused the steady-state voltage to increase to $51 \mathrm{mV}$ and $74 \mathrm{mV}$, respectively. These voltages were relatively constant over the time scale of the experiment. The reduction in temperature decreases the desorption rate of $\mathrm{CO}$, and therefore, is expected to affect the operational voltage. However, we assert that the measured differences are the combined effects both higher membrane resistance and reduction of the $\mathrm{CO}$ absorption rate. The cell temperature was then raised to 140 and $160^{\circ} \mathrm{C}$. As shown in Figure 8 ( $2630 \mathrm{hr}$ to $2870 \mathrm{hr}$ ), the cell voltages changed quickly with the changes in temperature. In addition, the cell voltages were very stable at each of the temperatures, and were nearly identical to the values observed earlier in this set of experiments. Within the experimental variables examined in this study, we conclude that the effects of $\mathrm{CO}$ on the catalyst are completely reversible at these temperatures.

The ability of the hydrogen pump to operate on contaminated gas streams that contain both $\mathrm{CO}$ and $\mathrm{CO}_{2}$ and to purify the hydrogen feed stream is a potentially important aspect of the high temperature operation. Thus, a cell was operated at two different current densities on the gas mixture described in Figure 8 and the $\mathrm{CO}$ and $\mathrm{CO}_{2}$ composition in the 
cathodic outlet stream were determined via on-line gas chromatography. The results of this test are shown in Table 1. The CO concentration was reduced more than 150 fold from $1906 \mathrm{ppm}$ to approximately $12 \mathrm{ppm}$. The $\mathrm{CO}_{2}$ concentration experienced a 32-62 fold reduction from $11.9 \%$ to $0.37 \%$ at $0.4 \mathrm{~A} / \mathrm{cm}^{2}$ and $0.19 \%$ at $0.8 \mathrm{~A} / \mathrm{cm}^{2}$. Diffusion through the membrane is believed to account for the low levels of contaminants in the purified hydrogen. At higher current densities and the resulting higher hydrogen flux rates, these diffusional based impurities are diluted and provide an even higher hydrogen purity. These experiments validate that high temperature PBI based pumps can operate in the presence of relatively high levels of $\mathrm{CO}$ and $\mathrm{CO}_{2}$, with and without external humidification, and on feed streams of low $\mathrm{H}_{2}$ concentrations. These simultaneous advantages are not possible with low temperature conventional membrane systems operating below $100^{\circ} \mathrm{C}$ because of catalyst poisoning and water management requirements. ${ }^{35,36}$

\section{Conclusions}

High temperature PEM cells based on PA-doped PBI were used to demonstrate the electrochemical pumping of hydrogen from various feed streams. The high temperature electrochemical hydrogen pump required relatively low power, while producing nearly Faradic flows and achieving excellent durability. Non-humidified and humidified operation was performed and the lower power requirements of humidified operation were tentatively ascribed to lower losses in the catalyst layer. The cathodic outlet flow was found to be relatively independent of the feed stream composition within the range of gas compositions tested and significant reductions in $\mathrm{CO}$ and $\mathrm{CO}_{2}$ levels were quantified. Long-term durability was demonstrated with a test that extended nearly 4,000 hrs. An electrochemical hydrogen pump that operates at ambient pressures in the presence of $\mathrm{CO}$, 
$\mathrm{CO}_{2}$, and $\mathrm{N}_{2}$ will be applicable to hydrogen recycling processes and purification from

biofuels, fossil fuels and reformed hydrocarbons with the potential to reduce purification

costs at large-scale production sites and point-of-use applications.

\section{Acknowledgments}

The U.S. Department of Energy, Basic Energy Sciences Division (DDE-FG02-

OSER 46258) and the National Science Foundation IGERT Program (DGE-0504361) are

gratefully acknowledged for support of this work. The authors would also like to thank H2

Pump LLC for assistance with the gas purity measurements.

\section{References}

[1] W. J. Koros, G. K. Fleming, J. Membr. Sci. 83 (1993) 1.

[2] W. J. Koros, R. Mahajan, J. Membr. Sci. 175 (2000) 181.

[3] M. Freemantle, Chem. Eng. News 83 (2005) 49.

[4] J. Larminie, A. Dicks, Fuel Cell System Explained, second ed., John Wiley \& Sons Inc. Hoboken, NJ (2003).

[5] S. Adhikari, S. Fernando, Ind. Eng. Chem. Res. 45 (2006) 875.

[6] M. Faroque, A. Kush, S. Abens, Sep. Sci. Technol. 25 (1990) 1361.

[7] F. Barbir, Hemijska Industrija 53 (1999) 426.

[8] S. H. Langer, R. G. Haldeman, U.S. Patent 3,475,302 (1969).

[9] H. J. R. Maget, U.S. Patent 3,489,670 (1970).

[10] J. Winnick, in: H. Gerischer, C. W. Tobias (Eds.), Advances in Electrochemical

Science and Engineering, vol 1, VCH. New York, 1990, pp. 205-210.

[11] J. Winnick, Chem. Eng. Prog. 89 (1990) 41.

[12] H. Matsumoto, T. Suzuki, H. Iwahara, Solid State Ionics 116 (1999) 99.

[13] H. Iwahara, Solid State Ionics 125 (1999) 271.

[14] S. H. Langer, R. Haldeman, Science 142 (1963) 225.

[15] K. Onda, K. Ichihara, M. Nagahama, Y. Minamoto, T. Araki, J. Power Sources 164 (2007) 1.

[16] H. Maeda, H. Fukumoto, K. Mitsuda, H. Urushibata, M. Enami, K. Takasu, in Fuel Cell Seminar. Orlando, FL, 1996, pp. 272.

[17] J. M. Sedlak, J. F. Austin, A. B. LaConti, Int. J. Hydrogen Energy 6 (1981) 45.

[18] R. Ströbel, M. Oszcipok, M. Fasil, B. Rohland, L. Jörissen, J. Garche, J. Power Sources 105 (2002) 208.

[19] B. Rohland, K. Eberle, R. Ströbel, J. Scholta, J. Garche, Electrochim. Acta 43

(1998) 3841.

[20] C. He, R. H. Kunz, J. M. Fenton, Hazardous and Industrial Wastes 31 (1999) 652. 
[21] K. Onda, K. Hattori, T. Ikeda, K. Ichihara, T. Araki, M. Terai, M. Igarashi, H. Kusada, T. Motoyoshi, in Fuel Cell seminar, Programs and abstracts. Palm Springs, CA (2005).

[22] H. K. Lee, H. Y. Choi, K. H. Choi, J. H. Park, T. H. Lee, J. Power Sources 132 (2004) 92.

[23] S. Gottesfeld, J. Pafford, J. Electrochem. Soc 135 (1988) 2651.

[24] R. Savinell, E. Yeager, D. Tryk, U. Landau, J. Wainright, D. Weng, K. Lux, M. Litt, C. Rogers, J. Electrochem. Soc 141 (1994) L46.

[25] R. F. Savinell and M. H. Litt, U. S. Pat 5,525,436 (1994).

[26] J. S. Wainright, J.-T. Wang, D. Weng, R. F. Savinell, M. Litt, J. Electrochem. Soc 142 (1995) L121.

[27] B. Cahan, J. Wainright, J. Electrochem. Soc 140 (1993) L185.

[28] M. Litt, R. Ameri, Y. Wang, R. Savinell, J. Wainright, Mater. Res. Soc. Symp. Proc. 548 (1999) 313.

[29] R. F. Savinell, J. S. Wainright, M. Litt, in Proton Conduction Fuel Cells II Editors PV 98-27, p. 81, The Electrochemical Society Extended Abstracts, Pennington, NY (1998)...Proceedings of the xxxth ECS Meeting, 1998.

[30] H. Moaddel, Ph.D. thesis, Case Western Reserve University, Cleveland, OH (1996).

[31] D. Weng, J. S. Wainright, U. Landou, R. F. Savinell, J. Electrochem. Soc 143 (1996) 1260.

[32] S. Wasmus, B. A. Dauch, H. Moaddel, L. Rinaldi, M. H. Litt, C. Rogers, A. Valeriu, G. D. Mateescu, D. A. Tryk, R. F. Savinell, in The $187^{\text {th }}$ Electrochemical Society Extended Abstracts, Ext Abstract \# 466p. 716, Reno, NV (May 21-26, 1995).

[33] L. X. Xiao, H. F. Zhang, E. Scanlon, L. S. Ramanathan, E. W. Choe, D. Rogers, T. Apple, B. C. Benicewicz, Chem. Mater. 17 (2005) 5328.

[34] B. Ibeh, C. Gardner, M. Ternan, Int. J. Hydrogen Energy 32 (2007) 908.

35. D. C. Papageorgopoulos, F. A. de Bruijn, J. Electrochem. Soc. 149 (2002) A140.

36. R. A. Lemons, J. Power Sources 29 (1990) 251. 


\section{Electrochemical Hydrogen Pump}

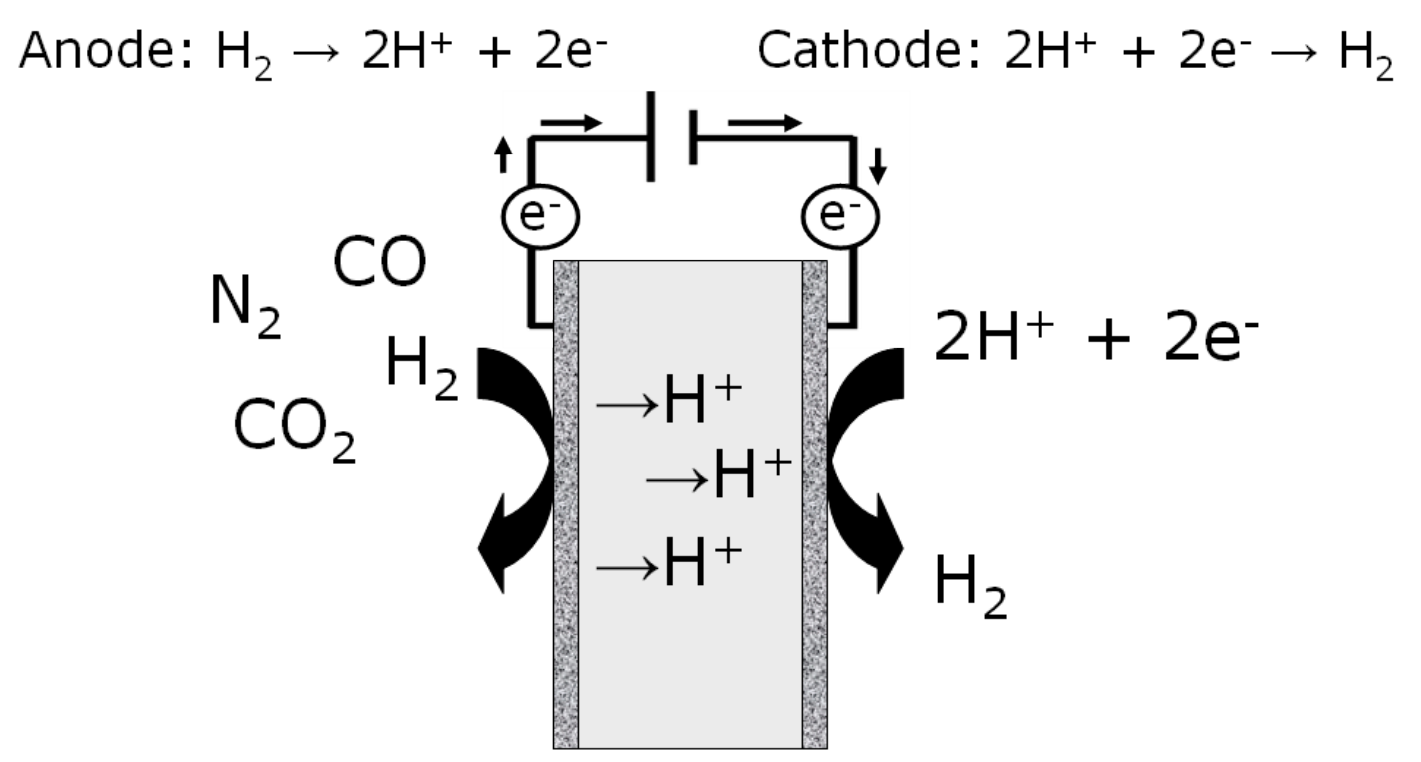

Figure 1. Schematic diagram of a high temperature electrochemical pump with a mixed gas feed stream. Anode and cathode half reactions are shown in the upper part of the figure. 


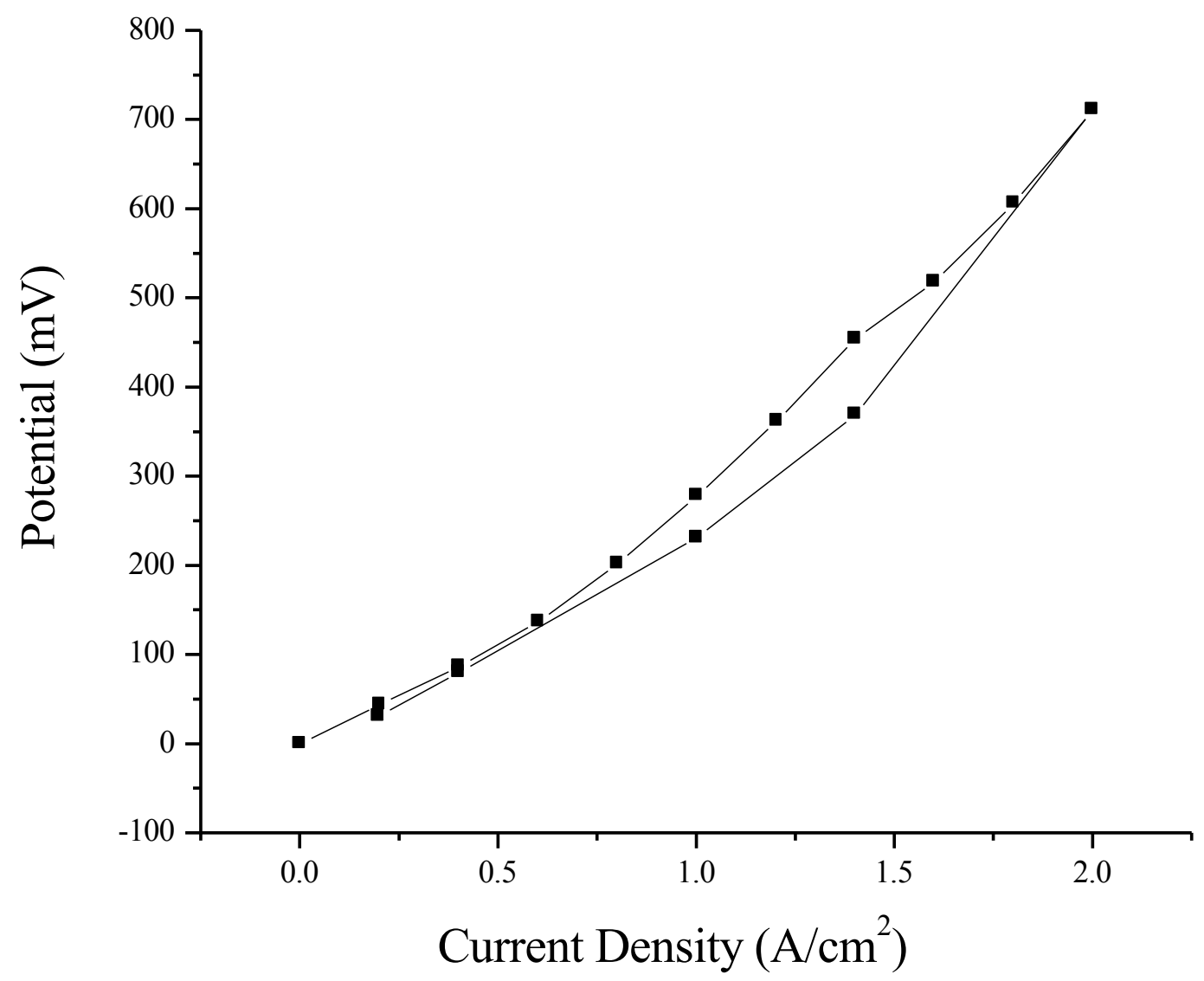

Figure 2. Polarization curve of an electrochemical pump operating on pure hydrogen without external humidification at $160{ }^{\circ} \mathrm{C}$. 


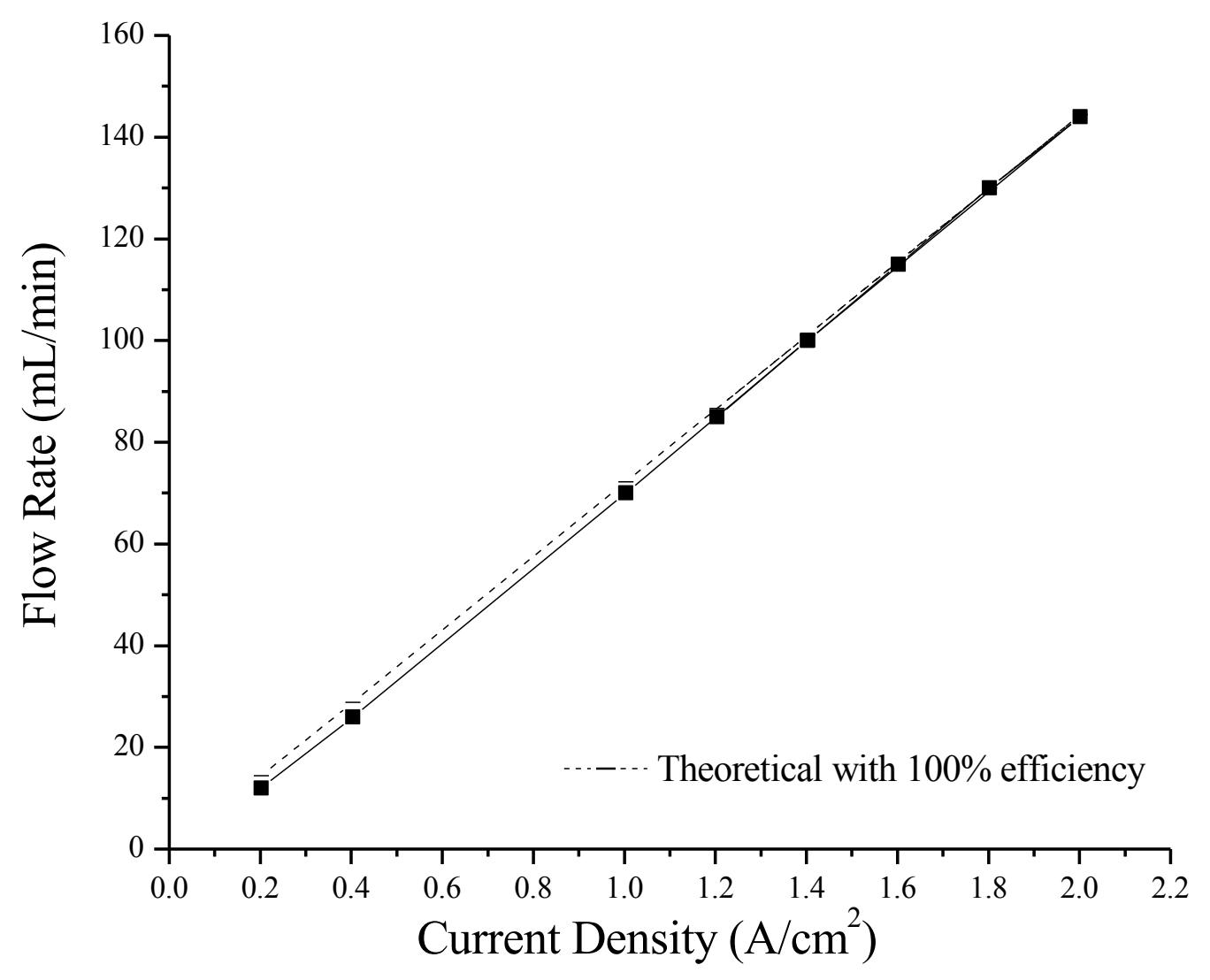

Figure 3. The cathodic outlet flow for a cell operating on pure hydrogen without external humidification at $160{ }^{\circ} \mathrm{C}$. The dotted line is the theoretical flow rate at $100 \%$ effieciency. 


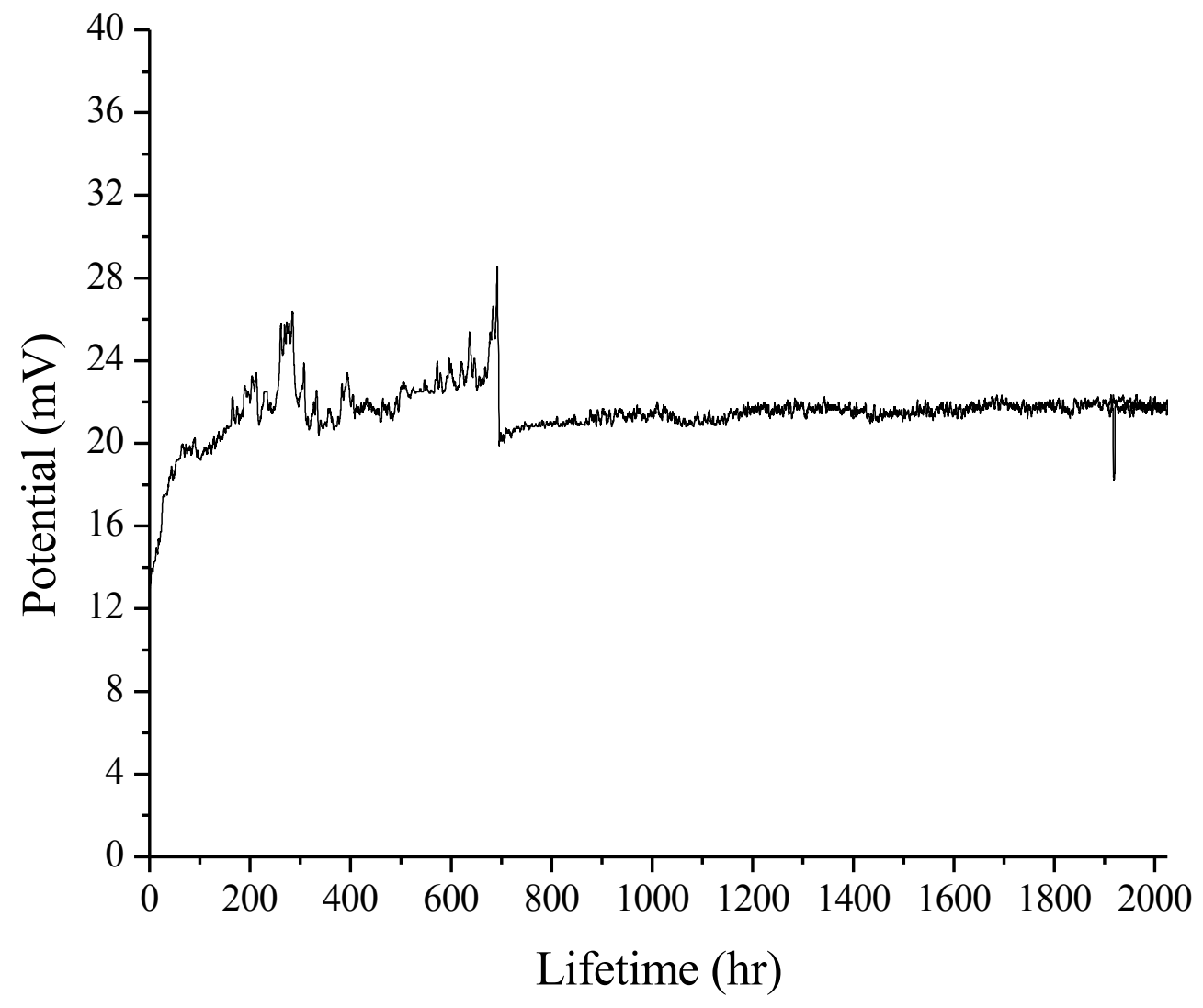

Figure 4. Long term operation of a hydrogen pump at $0.2 \mathrm{~A} / \mathrm{cm}^{2}, 1.2$ stoic dry hydrogen, $160{ }^{\circ} \mathrm{C}$. 


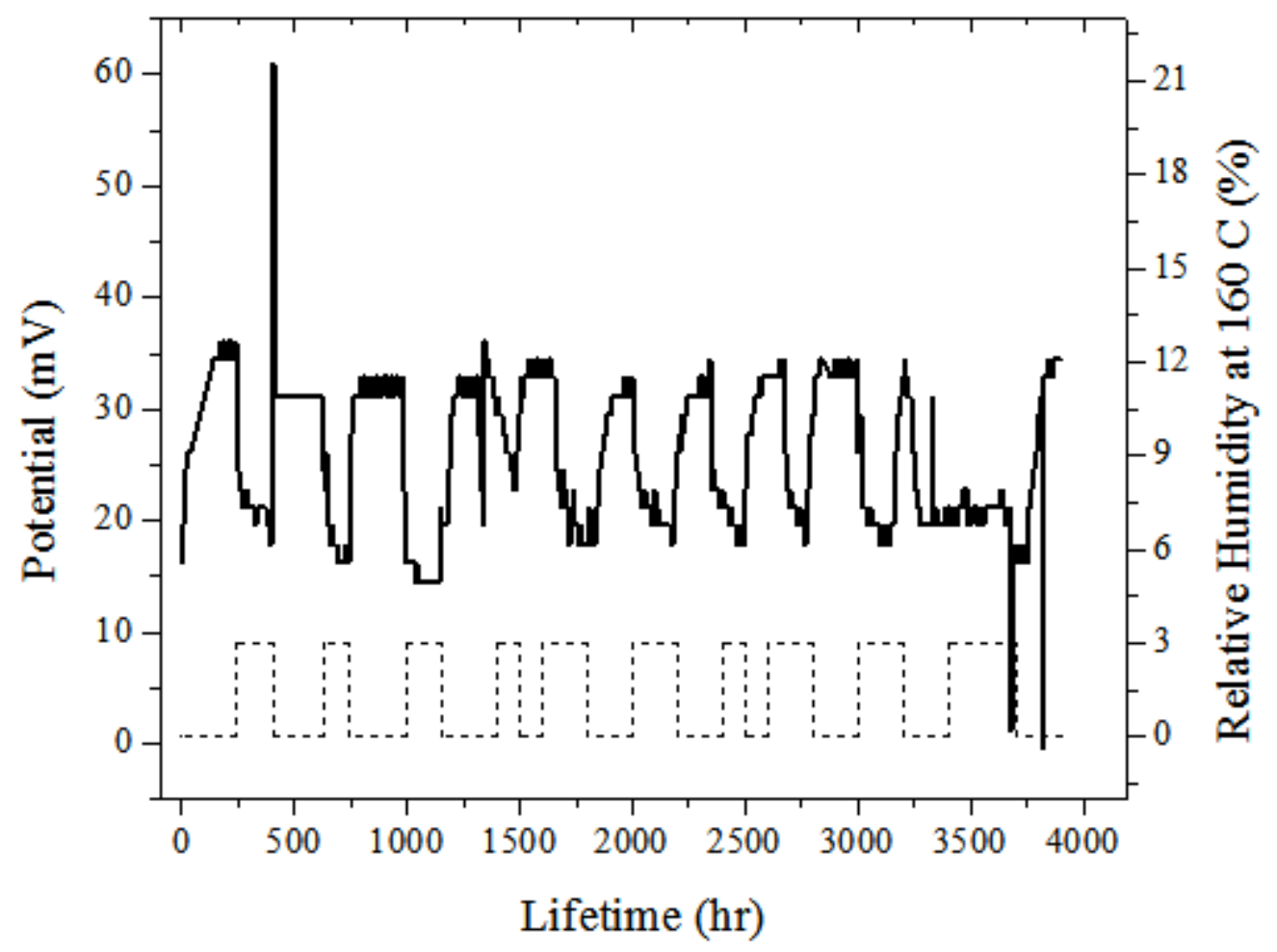

Figure 5. Long term operation of a hydrogen pump under alternating dry and humidified conditions $(0-3 \% \mathrm{RH})$ at $160{ }^{\circ} \mathrm{C}$. 


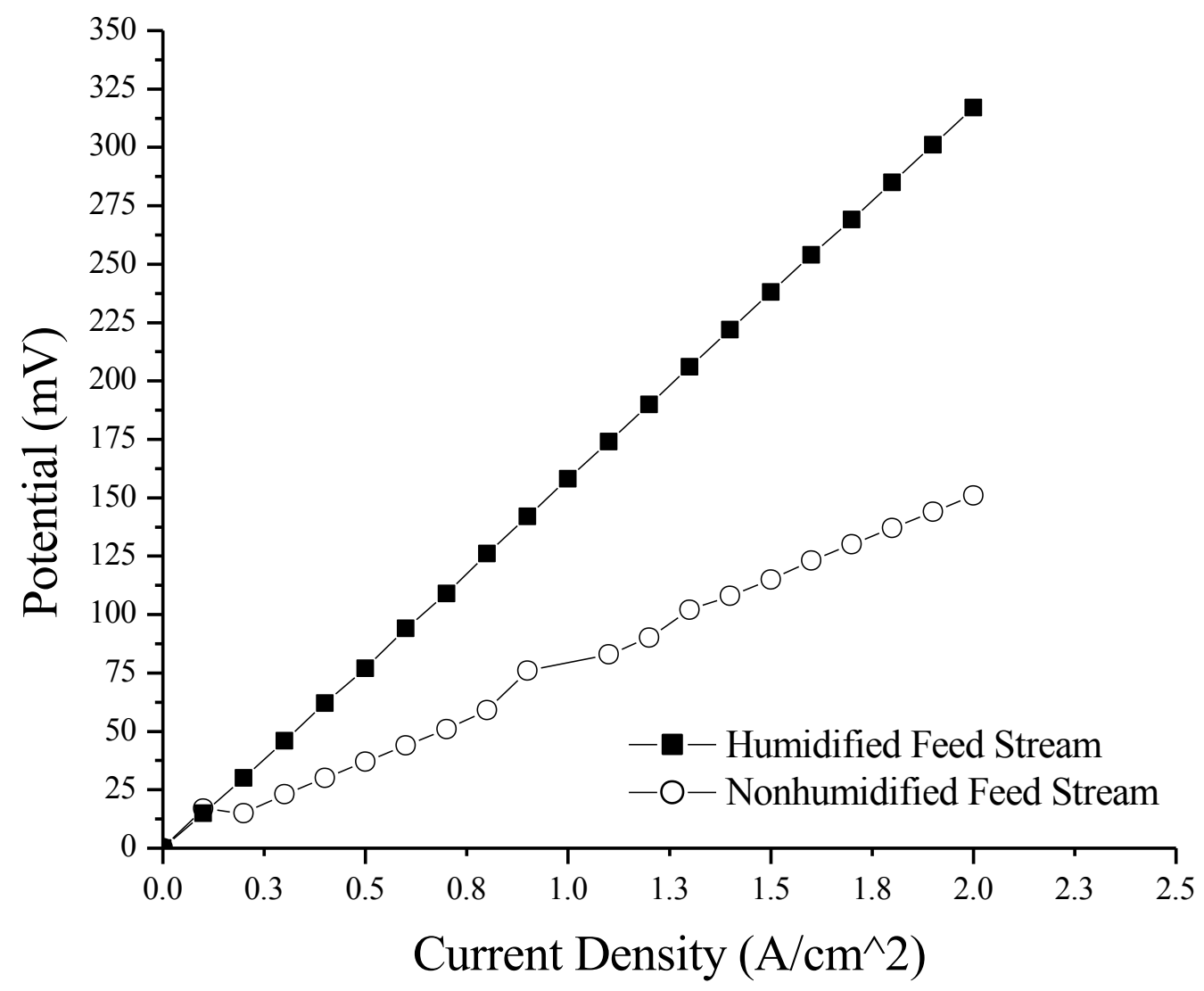

Figure 6. Polarization curves obtained under dry (at $1653 \mathrm{hr}$ ) and wet conditions (at 2144 hr) during long term operation. 


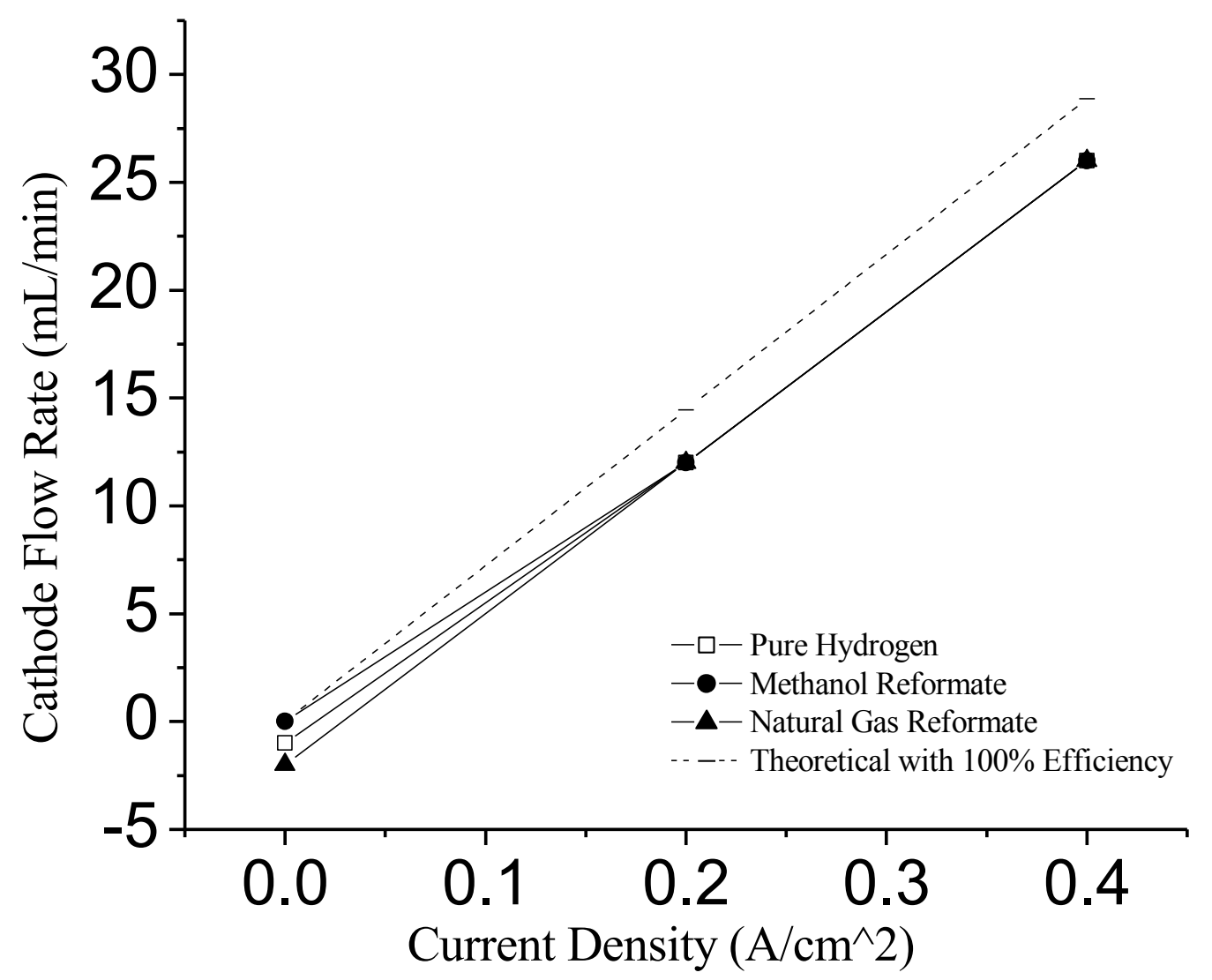

Figure 7. The cathodic flow rates for a hydrogen pump operating at $160{ }^{\circ} \mathrm{C}, 0 \% \mathrm{RH}$, on pure hydrogen (unfilled squares), a synthetic reformate containing $35.8 \% \mathrm{H}_{2}, 11.9 \% \mathrm{CO}_{2}$, $1906 \mathrm{ppm} \mathrm{CO}, 52.11 \% \mathrm{~N}_{2}$ (filled circles), and a synthetic reformate containing $69.17 \% \mathrm{H}_{2}$, $29.8 \% \mathrm{CO}_{2}, 1.03 \% \mathrm{CO}$ (filled triangles). The dotted line is the theoretical flow rate at $100 \%$ efficiency. 


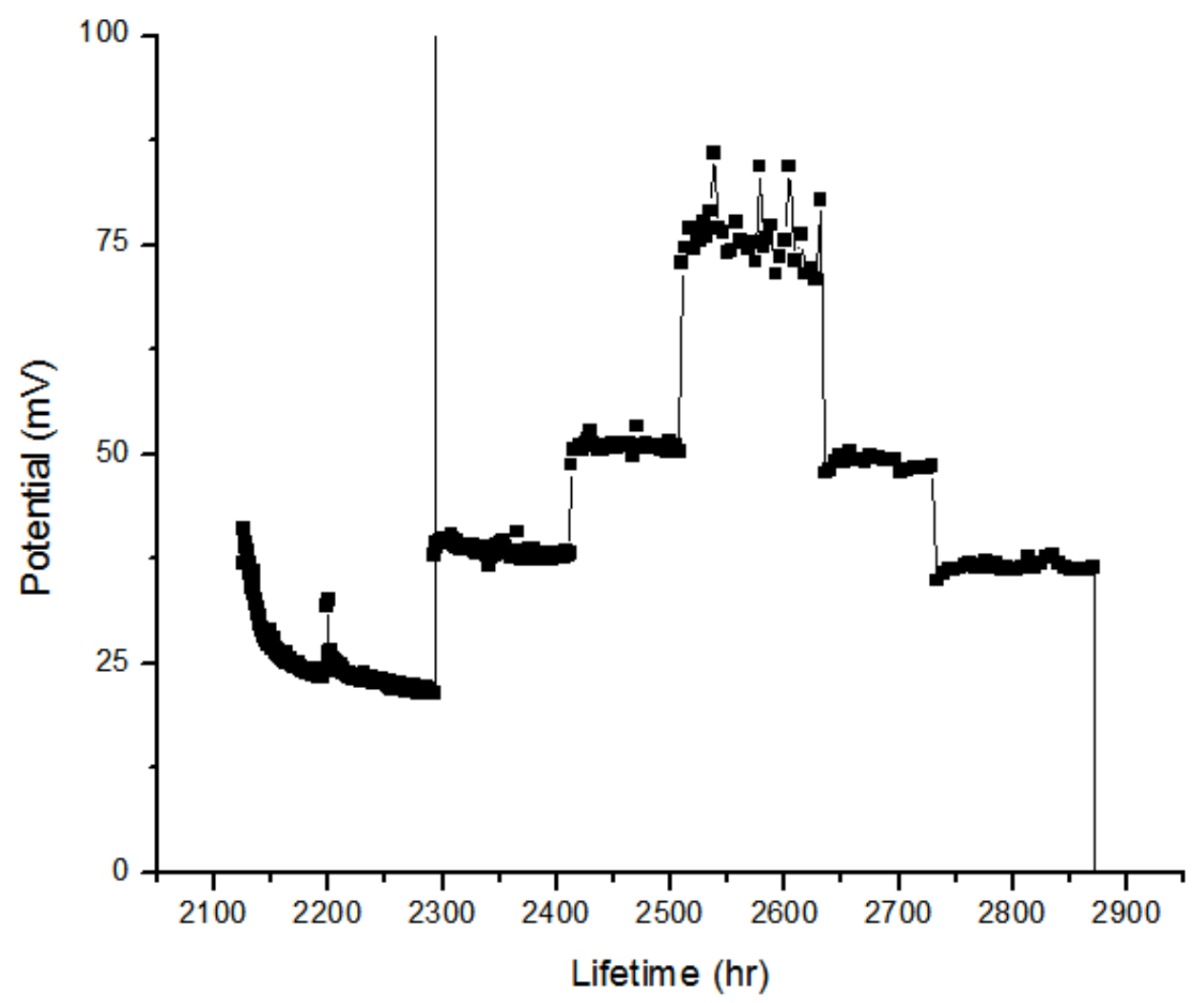

Figure 8. Effect of temperature on cell voltage for a hydrogen pump operating on a $1 \% \mathrm{CO}$ mixture at $160{ }^{\circ} \mathrm{C}, \sim 3 \% \mathrm{RH}$.

Table 1

\begin{tabular}{ccc}
$\begin{array}{c}\text { Current Density } \\
\left(\mathrm{A} / \mathbf{c m}^{2}\right)\end{array}$ & $\begin{array}{c}\text { Cathodic Outlet CO } \\
(\mathbf{p p m})\end{array}$ & $\begin{array}{c}\text { Cathodic Outlet } \mathrm{CO}_{2} \\
(\%)\end{array}$ \\
\hline $\mathbf{0 . 4}$ & $\mathbf{1 1} \pm \mathbf{1}$ & $\mathbf{0 . 3 7} \pm \mathbf{0 . 0 9}$ \\
$\mathbf{0 . 8}$ & $13 \pm \mathbf{3}$ & $\mathbf{0 . 1 9} \pm \mathbf{0 . 0 2}$
\end{tabular}

